Nadwa : Jurnal Pendidikan Islam

Vol. 13, No.2 (2019)

Accredited by Ristekdikti based on Decree No. 51/E/KPT/2017

DOI : 10.21580/nw.2019.13.2.5173

\title{
The Madrasa Resistance Against Radicalism
}

\author{
Ahmad Salim \\ Universitas Alma ata Yogyakarta \\ Email; ahmadsalim0305@almaata.ac.id
}

\begin{abstract}
The background of this article is based on madrasa resistance to radicalism. The purpose of this study is to see how madrasa resistance to face radicalism. The type of this research is qualitative research and data collection methods with observation and in-depth interviews with selected respondents. This study uses Peter L Berger's theory of the fundamental dialectics of societyexternalization, objectification, and internalization. The results showed that madrasa resistance to radicalism with social empowerment through the process of social construction (externalization, objectification, and internalization). The tolerant attitude of the community which is manifested in social humanitarian activities such as genduri, sambatan and kerja bakti is contracted by the madrasa as a subjective reality into objective reality, so that the antiradicalism attitude in this society can become the norm for the madrasas to be deprived and implemented in the daily life of the madrasa.
\end{abstract}

Keywords: Radicalism; Resistance; Social Empowerment; Madrasa

\begin{abstract}
Abstrak
Latar belakang artikel ini didasarkan pada resistensi madrasah terhadap radikalisme. Tujuan dari penelitian ini adalah untuk melihat bagaimana cara madrasah menghadapi radikalisme. Jenis penelitian ini adalah penelitian kualitatif dan metode pengumpulan data dengan observasi dan wawancara mendalam kepada responden terpilih. Penelitian ini menggunakan teori Peter L.Berger tentang dialektika fundamental masyarakat-eksternalisasi, objektifikasi dan internalisasi. Hasil penelitian menunjukkan bahwa madrasah menolak radikalisme dengan pemberdayaan sosial melalui proses konstruksi sosial (eksternalisasi, objektifikasi dan internalisasi). Sikap toleran dari masyarakat yang dimanifestasikan dalam kegiatan sosial kemanusiaan seperti genduri, sambatan dan kerja bakti dikontrak oleh madrasah sebagai realitas subjektif ke dalam realitas objektif, sehingga sikap anti-radikalisme dalam masyarakat ini dapat menjadi norma bagi madrasah untuk dicabut dan diimplementasikan di kehidupan sehari-hari madrasah.

Kata Kunci: Radikalisasi; Resistance; Pemberdayaan Sosial; Madrasah; genduri; sambatan; kerja bakti
\end{abstract}

ISSN 1979-1739 (P) ; ISSN 2502-8057 (E)

(C) 2019 Nadwa : Jurnal Pendidikan Islam / UIN Walisongo.

Accredited by Ristekdikti based on Decree No. 51/E/KPT/2017

http://journal.walisongo.ac.id/index.php/nadwa 


\section{Introduction}

The rise of terrorist acts lately in New Zeland, America, Asia, including Indonesia, has restored the memory of all people of the danger of the tenet of the radical islamic movements and their radical acts. It's all because in any teror acts, directly link with islamic religious movements which tend to embrace radicalism.1 It's mean that there are mutual relationship both terrorist act and radicalism. It has beared and stimulated many terrorist acts. Seeing the link between radicalism and terror above, it can be said that radicalism does not stop at understanding and thinking alone, but the concept of radical Islam has been exhibited by some groups by bringing Islamic attributes and jargon, and it is claimed as an act of worship.2

Radicalism does not only grows in one place, but various aspects of life can become fertile ground for its growth and development. Educational institution is an efective place to transmite and develop the concept of radicalism. Education can become instrument and way to internalize the islamic radicalism on student's dayly activities and networking which is used to sosializing that paradigm into communities. Likewise with islamic education side, radical understanding of religion comes from radical education. In line with Iqbal Ahnaf statement; for some young people, including teneeger still in midle school is one segment of the community who are most vulnerable to be influed by radical ideologi and terrorism. Success of radical and terrorist gruop recruiting young people can not be separated from social

1 Husniyatus Salamah Zainiyati, "Curriculum, Islamic Understanding and Radical Islamic Movements in Indonesia," Journal of Indonesian Islam 10, no. 2 (2016): 285-307, https://doi.org/10.15642/JIIS.2016.10.2.285-308.

2 Nanang Hasan Susanto, "Menangkal Radikalisme Atas Nama Agama Melalui Pendidikan Islam Substantif," Nadwa 12, no. 1 (2018): 65, https://doi.org/10.21580/nw.2018.12.1.2151. 
political landscape which is the structure of political oppurtunities. 3

As an Indonesian education system, madrasa is institution that provides education from elementary to high level education. Education is part of social change and if possible social change needs and can be influenced by education. 4 The meaning of the relationship between madrasa and the community is shown by the extent of education services to the community which ultimately is the transformation community. This means that between madrasa and communities are an inseparable unity, the presence of madrasa in the community is a necessity in the context of meaningfulness or benefit to the community.

The link between madrasah with society has implications for the dependence among them cannot be released. The anvancement or progress of the school in a community will certainly stimulate the progress of the community concerned, and vice versa. Changes in student behavior are not only the result of learning in school, but also come from outside the school including the community where the school is located. Some networkings or even the community environment that allows students to interact with it is very likely to affect changes in student behavior, including on the dimension of radical religious changes. In the context of learning process on school, Dirga Maulana said that, increasing radicalism in educational institutions in Indonesia is associated with particular models of interpretation, understanding, teaching, school of thought, denomination, and even sect within particular religion. He added

3 Mohammad Iqbal Ahnaf, "Struktur Politik Dan Deradikalisasi Pendidikan Agama Bagi Anak Muda Di Indonesia," Jurnal Pendidikan Islam 2, no. 1 (1970): 153, https://doi.org/10.14421/jpi.2013.21.153-171.

4 H.A.R Tilaar, Perubahan Sosial Dan Pendidikan, Pengantar Pedagogik Transformatif Untuk Indonesia (Jakarta: PT. Grasindo, 2002). 


\section{8 | Ahmad Salim}

that, rigid, exlusive and close minded interpretation of religius text beared increasing radicalism toward students. 5

Based on author's observations in MAN 3 Kulon Progo, the religious understanding of madrasa students is still low and and it very vulnerable, including radicalism idology. The author will not see the connection between weak of understanding of students' religion with the inclusion of radicalism in the madrasa, but the author will focus more on the discussion of the deradicalization of madrasa through social empowerment of the community. The author will look further at the relationship between community empowerment toward deradicalization of madrasa with used qualitative analysis at MAN 3 Kulon Progo and sorounding societies. Data were collected by performing observation and indepth interviews to sellected respondents and this research was conducted from October to December 2019. Apparently, many schoolars have tried to explain these radicalism phenomena, most of which using cultural, economic, even political analyses. It is in line with Zainiyati's notionn6, that deradicalism program, in a board sense, should be approached in a holistic manner, in eliminating the radical understanding. Without disregrading with these analyses, author will analize it by using cultural approach, mainly through sosial capital to describe madrasa's deradicalization through community/society empowerment.

\section{The Importance of Radicalisme Resistance in Indonesia}

5 Dirga Maulana, "The Exclusivism of Religion Teachers: Intolerance and Radicalism in Indonesian Public Schools," Studia Islamika 24, no. 2 (2017): 395-401, https://doi.org/10.15408/sdi.v24i2.5707.

6 Zainiyati, "Curriculum, Islamic Understanding and Radical Islamic Movements in Indonesia." 
Religious radicalism which is interpreted as fanatical about one opinion and eliminating another opinion, ignoring the historical Islam, not diolouge, consider whom differ from him is kafir, and textual in understanding religious texts without considering the essence of the Shari'a.7 Rubaidi further elaborated on some radicals' characteristics, including; making Islam as the final ideology to regulate individual life or state administration, taking Islamic values from the Middle East as is or without being adapted to the context of the age and place and purification of Islamic teachings from non-Islamic teachings including local and western cultures.8 The Islam history proves that fanaticism and excessive exclusivism are one of the keys to the emergence of radicalism.

In the sociological context, as mentioned by Muhammad Iqbal Ahnaf taking Demant's opinion, Slootman said that radicalization is more interpreted as a process of strengthening "delegitimization" of the social system and environment. Individuals and groups radicalization is characterized by a decline in confidence in the established social-political order and also attempts to withdraw from social relations outside of their group. 9 So, in general it can be seen that the radicalist movement often has exclusive relations, separate from other established groups, and tend to form new and completely different groups.

Responses toward the backwardness of the Islamic world in such various aspects of life in this world, including in Indonesia which is caused by the political attitude of the Order Baru

7 Irwan Masduqi, "Deradikalisasi Pendidikan Islam Berbasis Khazanah Pesantren,” Jurnal Pendidikan Islam 2, no. 1 (1970): 1, https://doi.org/10.14421/jpi.2013.21.1-20.

8 Rubaidi, Radikalisme Islam, Nahdlatul Ulama; Masa Depan Moderatisme Islam Di Indonesia (Yogyakarta: Logung Pustaka, 2010).

9 Ahnaf, "Struktur Politik Dan Deradikalisasi Pendidikan Agama Bagi Anak Muda Di Indonesia." 
government that marginalized Islam, have given rise to the seeds of radicalism in Indonesia to grow. The point of view that claim communist and secular ideology have been proven to fail to bring prosperity to the citizen in a country also stimulates the growth of this radical movement in the hearts of its bearers. Radicals believes that Islam glory can be returned by carrying out a solution to the application of Islam in total, including the Indonesian government system.

In fact, the trace of radicals in Indonesia is a past phenomenon, at least in aspects of concepts and thinking. But the emergence of radicalism, which in the context of a massively and openly movement has only found its momentum after the fall of the Order Baru era. Radicalism kept at bay due to political repression of that era. Transition for democracy has opened the space for radical groups to emergence.10 Started from the Order Baru era which placed Islam as a marginalized movement of political and social policymakers. Getting even worse, its movements could sometime be suspected of being obstacles and also rebelling from the government's development program. The marginalization of Islam in the practical political sphere can be seen in the limitation of political parties, that is, only the unity development party as a representation party of Islam.

At the end of the Orde Baru regime, Islam was only given its opportunity to play more roles to implement some of its movement's missions, at that time - then - many different schools of Islam emerged. The transition from an authoritarian system to democracy opens up opportunities for the flourishing of various schools including radical movements. As a movement, this

10 Ronald Lukens-Bull, "The Traditions of Pluralism, Accommodation, and Anti-Radicalism in the Pesantren Community," Journal of Indonesian Islam 2, no. 1 (2008): 1-15, https://doi.org/10.15642/JIIS.2008.2.1.1-15. 
radical ideology found its momentum when democracy enabled it to grow and develop its influence to wider community.

Freedom to associate and assembly as one of the characteristics of democracy, has enabled the opening of wider social relations in society and resulted in dialectics between communities, and even countries, to occur. The euphoria of massive social relations during the reform era resulted in transnational ideology that could enter and influence the paradigm of Indonesian Muslims. As a result, many movements are influenced by radical movements from the Middle East. Other scenario was to accept those Middle East movements as they are and were implemented as Indonesian radical movements which had played major roles for violent movements that occurred in this country throughout the reformation period.

This form of radical flo w movement always leads to a spectrum that the Indonesian constitutional system is not in accordance with what they are fighting for, therefore the Indonesian government system must be replaced with the khilafah system. In order to fight for the ideal form of government system that they aspire to, radical groups carry out various forms of "struggle" including violence. Some forms of physical or psychological violence which were carried out massively by radical groups throughout the Reformation period have made most of Indonesian people aware of the potential dangers of radicalism.

Since the movements carried out by this group tend to use violence in fighting for their desired government order, there was strong resistances from the community. This rejection response was represented by two of the mainstream Islamic organizations in Indonesia; Nahdatul Ulama and Muhammadiyah. Those two largest and most powerful Islamic organizations expressly reject the violence carried out by radical groups as they realize that 
radical movements are always carried out in the name of religion.11 For these two mainstream religious institutions, the Unitary Republic of Indonesia is the final system of government proven to be in harmony with the diversity of the Indonesian people. It is clear that the radical struggle movement is contrary to the spirit of Islam struggle itself, Islam which provides peace for all nature. The radicalism movement actually caused unrest in society, especially regarding the desire to revive the system of khilafah and violence in several regions in Indonesia by this destructive movement.

\section{Radicalism Potentiality in Madrasa}

Radical fighters use various means and media to coordinate and strengthen their internal organizations. They also use various methods to disseminate their ideology of radicalism. Madrasa as an educational institution is one of the important instruments for the socialization of radicalism to students. As an education system, madrasas have strong legitimacy to "impose" their program through designated activities. The socialization aims to seek attention, sympathy and influence on students so that students can follow this radical ideology. Starting from sympathy and internalizing the teachings of radical ideology, eventually students are bound and become part of this radical group.

Some forms of extracurricular activities in madrasa can be a place for this radical teaching to grow and develop. Through Rohis they can design religious social activities and religious guidance towards radical teachings. Generally, the design of these activities is made as simple as and as interesting as possible to suit the student development. This attracts many students getting interested in some of these labeled-as-religion activities.

11 Rubaidi, Radikalisme Islam, Nahdlatul Ulama; Masa Depan Moderatisme Islam Di Indonesia. 
Teacher's attitude and understanding of Islamic teachings is also a determining factor for the proliferation of radical ideas in madrasas. The teachers' role as a learning actor allows them to design programs and activities in madrasas to suit the learning outcomes that they wants to achieve. A teacher who has a radical understanding, therefore, can easily influence his students to follow a radical understanding, especially when he is supported by the socio-economic conditions of the students' families that are loaded with these teachings. Teachers and the environment can create students' social spaces, and when this social space is constantly dominated by radical narratives, the opportunity to cultivate radical ideas will be more wide open. 12

The sociological conditions of the community around MAN 3 Kulon Progo as the basis for the spread of Christianization 13 support the radical narrative developing in this madrasa. However, radicalism in madrasa students appears in the form of concepts and thoughts that lead and support conservative actions, such as agreement on the literal application of Islamic law and consider that religion other than Islam as a threat to the existence of its diversity.14 Based on previous researches, the authors have not found radicalism in physical form by committing violence and terror. The author sees several students dressed in long hijabs, and after we have had discussions with them, most of them have a literal understanding of religion and want to be led by Muslims,

12 Ahnaf, "Struktur Politik Dan Deradikalisasi Pendidikan Agama Bagi Anak Muda Di Indonesia."

13 Nawari Ismail, "Konflik Umat Beragama Dan Budaya Lokal" (Jakarta: Dirjend Dikti, 2010).

14 Result of Interview with students' MAN 3 Kulon Progo (on October 16, 2019). They also said that Christians around madrasa which is religions that would threaten Muslims in various ways, they also disagreed if led by Christian village heads, agreed if Islamic law was applied literally, for example the law of cutting off hands for thieves. 


\section{4 | Ahmad Salim}

but they understand that as a plural society it must be concerned with tolerance to maintain unity. It's means that radicalism appears still in the context of thought has not yet arrived at the act of spreading its understanding to other students.15 After the Author cross-check toward other respondents, the condition of the students mostly came from Junior High School (SMP) students.16

Based on the field research, student relations outside the madrasa contribute more compared to the internal factors the radicalism emergence. Ease of access to information about radicalism in online media, partial acceptance of religious material to students is a form of social space outside the madrasa that encourages the emergence of radicalism for students. Social changes in the community around students 'dwellings contribute greatly to students' understanding of the teachings of Islam, so students tend to be permissive and adaptive to various changes, including those related to religious paradigm changes.

MAN 3 Kulon Progo has made various efforts related to the protection of the radicalism spread. Various forms of radical protection activities are through the socialization of the importance of being tolerant to other religions in learning in the classroom or some humanitarian social activities that directly intersect with wider community.17 All subject teachers, especially PAI teachers always give students an understanding of the dangers of radicalism for religious harmony.

Madrasa's teacher has also provided a comprehensive understanding of radicalism primarily related to the issue of jihad.

15 The results of the field research above are consistent with the results of an interview with Siti Muflikah (Curriculum Deputy) on 7 October, 2019.

16 Result of interview with Suwata Hariyadi (Counseling Teacher) and Tursubi (Administration Officer) on 11 November, 2019.

17 ResuIt of interview with MAN 3 Kulon Progo Principal on October 2, 2019. 
Jihad is not only focused on physical war but can be directed towards several activities that require a large amount of energy, for example; seeking knowledge, serving parents and giving wealth to those in need. The teacher also emphasizes the importance of tolerance to be internalized to all madrasa students in order to maintain religious harmony in the area around the madrasa that is plural on the religious side (Muslim-Christian).18 Internalization of tolerance is also implemented in humanitarian social activities, such as attending Christian families burial ceremony, visiting sick friends, social servicing to madrassas surrounding environment that are mostly Christian, and house renovation programs which is initiated by the madrasa scout unit. 19

\section{Radicalism Resistance with Sosial Empowerment}

The social shift that created the transition of traditional society towards modern society contributed greatly to the strengthening of students' religious paradigms. Ease of access to information as a characteristic of modern society also influences students' attitudes in taking their knowledge preferences about religion. Madrasa teachers are not the only single truth that can be used as the main reference about religion. The truth about religion that students get through teachers in madrasas is something that is subjective and can be contrary to the truth of religion that comes from outside the madrasa. Dialectics of students with society at large have created social spaces that can

18 In accordance with Core Competencies 2 MA grade X and XI which state live and practice honest, disciplined, responsible, caring mutual cooperation, cooperation, peace tolerance, responsive and proactive behavior and show attitude as part of the solution to various national problems and position as an agent the transformation of society in developing the face of the nation and the world.

19 Result of interview with Parwanto (Aqidah Akhlak Teacher) dan Nur Salim (Fikih Teacher) on 13 October, 2019. 
allow understanding of student religion to change and differ from the perspective of teachers in madrasas. Student activities outside the madrasa, in the form of social humanitarian activities, sports groups, art groups that exist in the student environment contribute to contribute to the shift in the religious paradigm of madrasa students.

Psychological and physical development of madrasa students who are in adolescence contributes greatly to changes in students' attitudes and religions 20 from outside madrasa influences that tend to be free and uncontrolled from strict bureaucracy, as in madrassas. Unstable teenage conditions and high curiosity about something new encourage students to look for something different from mainstream teachings that have been established before. Modernization that is loaded with technology, especially transportation and communication technology, makes it easy for students to explore their knowledge, including in the religious field. Changes in students 'attitudes and behavior as a result of social change in their environment provide an opportunity for the growth of radical understanding to influence students' religious paradigms. This condition can encourage students to think that mainstream religious beliefs that have been established so far have experienced boredom and stagnation, do not respond to social problems, thus allowing students to be attracted to new ideas that are considered to be able to overcome various kinds of problems.

Based on some of the theories above, the deradicalization efforts which only rely on internal education, including madrasas, are unwise expectations. Deradicalization must lead to a strong synergy between the madrasa and the community where the madrasa is located. Deradicalisation efforts must be able to create reciprocal relations between madrasas and the community, so that

20 W.A Garungan, Psikologi Sosial (Bandung: Eresco, 2008). 
their success can be felt in the daily lives of students both in madrasas or in the environment of students located.

The government as a formal authority that has strong power over the community has made efforts to deradicalize various forms of regulation and the accompanying policies.21 Various community empowerment activities have been carried out so that the community will be socialized about the importance of a tolerant attitude towards plural society and vice versa the danger of radicalism towards the harmony of society and the state. Although in Berger's view the state has full legitimacy to "force" the community to objectify subjective reality towards objective reality22, but various forms of empowerment will not succeed optimally without the social role of the community itself. The social structure of the community around MAN 3 Kulon Progo has taken their respective roles in social empowerment, to create a tolerant and anti-radical society. Mosques, Islamic boarding schools, orphanages and churches are examples of socio-religious structures that empower hill communities known as Menoreh hills.

The mosque which is located near the madrasa performs its role either as a ritual center or a place for social empowerment in the context of strengthening people's tolerance. The division of Friday prayer sermons between NU and Muhammadiyah followers and accommodation to both praying procedures are some examples of the implementation of tolerance in internal

21 See. PP No 77 Tahun 2019. concerning the prevention of criminal acts of terrorism and protection of investigators, public prosecutors and judges and officers. This regulation is more focused on efforts to deradicalize people who have been exposed to radical ideology, with various programs; rehabilitation, reintegration and reeducation.

22 James M. Dixon and Peter L. Berger, "The Sacred Canopy: Elements of a Sociological Theory of Religion," Sociological Analysis 29, no. 1 (March 21, 2007): 40, https://doi.org/10.2307/3710433. 
Islam shown by the mosque management. The distribution of sacrificial meat to Christian residents around mosques and congratulations on Eid al-Fitr from Christians to Muslims around the madrasa is a form of tolerance building that has been running in the community around the madrasa.

In addition, other social organizations such as Jaga Warga and Karangtaruna also implement forms of harmony and tolerance in the various activities carried out. They competed in independence events, village anniversary celebrations, community service to eradicate landslides without distinguishing their religious groups and ideologies. Some madrasa students participated in the activity, especially students who lived in the same village as the madrasa. They are affiliated with Karang Taruna, Banjarroya Village and consist of a number of youths who are interfaith (Muslim-Christian). This building of tolerance will also reduce the radical attitude both in Muslims and Christians, because between them there are complementary relations and dialectics in the humanitarian context.

The $P K K$ social gathering group in Patog Hamlet, Banjarroya Village, Kalibawang also did almost the same thing in strengthening the value of harmony and tolerance. The arisan group that carries out its activities every Monday afternoon hold some savings and loans, organize social gathering, and set aside part of its balance for humanitarian/social activities such as visiting its members who are sick regardless of differences in religion. This activity will automatically strengthen the tolerance and reduce the radical attitude. Their concern for their group will strengthen solidarity and increase anti-radicalism among them.

In the context of Islamic boarding schools, efforts to strengthen tolerance are carried out by internalizing the value of tolerance in learning and other activities that directly intersect with the community. The involvement of students in community 
service around Islamic boarding schools in the Christian community is a form of concern that can strengthen the sense of tolerance between Muslims and Christians.

In MAN 3 Kulon Progo, the realization of tolerance and antiradicalism has been engraved in the daily life of the community through several activities that have become a noble legacy for the creation of community harmony. This social activity is able to bring people together regardless of their social and religious status. Some of these activities are;

1. Interfaith Genduri

Genduri is a tradition of praying for the safety or success of what is being done to the God by gathering of at least two people who can be from relatives, neighbors and or colleagues.23 As an activity to ask for salvation, the community usually carries out genduri when they carry out marriages, circumcisions, memorials of deceased relatives and thanksgiving for achieving expected thing. This genduri tradition is an activity that brings people together without distinguishing one's social and religious status. Through this activity, they all ask for salvation from their respective Gods. Christians are also obedient to the rules of this procedure, including the procession of prayer even though the one who leads the prayer is a Muslim.

The procedure for obesity is indeed changing along with the social changes of the community, one of which is due to the heterogeneity of the work of the community around the madrasa. Changes occur at the time of implementation, the equipment for the fat and how to invite residents to carry out the fat. During the implementation, the procedure for the fatman is more flexible with the adjustments to the bustle of

23 Clifford Geertz, Abangan Santri, Dan Priyayi Dalam Masyarakat Jawa, Terj. Aswab Mahasin (Jakarta: Pustaka Jaya, 1981). 
the people and the development of existing modernity. The time for genduri is mostly carried out at night, and in the morning with selected holidays, for example Sunday, and the implementation of genduri is more simple so that it does not interfere with other activities of the residents.

The way to invite neighborhood to carry out genduri also changed. In the past, people came to each neighborhood house and delivered the genduri invitations verbally, now the invitations are used, sometimes they announced the invitation through $R T$ meetings or social gathering. The changes that do not reduce the essence of the meaning of obesity that is a request for citizens' safety and also contained the meaning of the reality of harmony between citizens. Harmony is reflected in that all citizens can participate in this event without being limited by certain social statuses. That kind of meeting in this frame of harmony clearly reinforces the sense of community unity and tolerance and vice versa will eradicate the radical attitude.

Berkat, a food brought home by residents who carry out the genduri, is a form of gift given by the genduri holder to those who cannot coming to the genduri. The Berkat will still be sent to those residents who are unable to attend the genduri procession. This reality is a form of appreciation for neighborhood who are still have to do another business and therefore unable to attend the genduri.

This reality is an attitude of caring that can increase tolerance among citizens and dispel radical attitudes. This action contained reciprocal relationships that connect people who have intentions with other citizens. Citizens who are invited to carry out genduri will do the same for people who carry out the ritual at a later time, regardless of social or religious status. The social space which is constructed through this 
procession of genduri can bring together Muslim-Christians in the humanitarian context. The relationship that was built prioritizes harmony based on strengthening religious tolerance to all citizens.

2. Gotong royong (mutual cooperation)

Koentjaraningrat classifies mutual cooperation as a form of activity, helping with indicators is that the activity is intended to resolve the needs ("gawe") of individuals in the community, based on reciprocity principles and problems can arise if someone does not respond to the provision of services that have been provided either in the form of labor or certain objects.24 Mutual cooperation activities involving residents in the context of a smaller relationship than genduri. Citizen involvement in mutual cooperation activities is more focused on the social environment they live in, for example in the $R T$ context.

Mutual cooperation is carried out if the residents or social structures in an area have a large job that cannot be carried out independently or with the help of the residents, the work carried out will be completed more quickly. Thus, the form of mutual cooperation can be associated with activities such as "sambatan", "kerja bakti" and "rewang". Although all three of these activities have connected with one another, but each has different specifications.

Sambatan is carried out if the residents have jobs that require the help from many people, for example building a house and / or kitchen. The residents who help the work are usually treated with a variety of foods including lunch and supper. The focus of this activities is directed at one citizen who needs help. Kerja bakti is carried out if the social structure of

24 Amri Amzani, Antropologi \& Pembangunan Masyarakat Indonesia (Jakarta: Kencana, 2009). 
the community at a certain level, for example $R T$ has jobs that require large numbers of people to carry out. The focus of the work is for broad social interests, such as cleaning roads, building substations or renovating places of worship. Kerja bakti usually does not prepare lunch, but only provide snacks. Rewang is more carried out when residents have certain events, for example marriage, circumcision, thanksgiving. Residents help the residents who currently have large works until the event is over.

These three forms of social activity are classified as mutual cooperation activities which have implications on reciprocal social relations.25 A resident who has received assistance from another resident will feel the same obligation to provide assistance to the person who has helped him. A person who has never carried out mutual cooperation activities will automatically feel excluded from the community concerned.

The harmony of society which is shown by the solidity in doing communal work will strengthen the tolerant attitude among them. The strength of the tolerance building among people is actually an important asset for strengthening anti-radicalism in the community. The highest indicator of anti-radicalism is actually tolerance. This is caused by the tolerant attitude which is contained in the acceptance of the truth that is believed by others. Accepting that truth is in others is the most concrete form of antiradicalism.

In the community that close to MAN 3 Kulon Progo, it seems clear that community empowerment is more pivoted on the

25 Rauf Hatu, "PERUBAHAN SOSIAL KULTURAL MASYARAKAT PEDESAAN (Suatu Tinjauan Teoritik-Empirik)," Journal Inovasi 8, no. 4 (2011):

$1-11$, https://scholar.google.co.id/scholar?hl=id\&as_sdt=0\%2C5\&q=PERUBAHA $\mathrm{N}+\mathrm{SOSIAL+KULTURAL+MASYARAKAT+PEDESAAN \& btnG=.}$ 
utilization of social capital 26 owned by the community to create a balance of life by building and strengthening community harmony. Community harmony life will be created if tolerance between citizens is well established. Mutual trust between citizens, values and networks owned by the community is an important social capital to create a sense of tolerance between people and reduce the attitude of radicalism between them. With the social capital they have, tolerance can be created and developed in several social humanitarian activities.

The existing humanitarian social activities are able to accommodate the diversity of the community on various sides, both social, economic or religious status, thereby eliminating these barriers. Religious partition which often leads to intolerance and radicalism is reduced by the desire to create harmony in society. Sociologically, most of the people around the madrasa are still related to one another. This reality is a strong reason that harmony among citizens is more valuable than promoting an attitude of intolerance and radicalism that will clearly destroy the harmony of their lives.

The success of strengthening both tolerance and antiradicalism of this community has an effect on the madrasa's antiradical attitude. MAN 3 Kulon Progo as an educational institution which born from the community, it is easier to follow the norms and attitudes practiced by the community. The synergy of madrasa and society in combating radicalism found a meeting point in an attitude that prioritizes harmony.

In the context of Berger, madrasa responses to the reality of tolerance and anti-radical attitudes in the community are interpreted as socialization of the community to contract subjective reality towards objective reality. The process of

26 R Putnam et al., “"The Prosperous Community: Social Capital and Public Life,"” The American Prospect, 1993. 


\section{4 | Ahmad Salim}

changing subjective reality into objective reality is done through externalization, objectification and internalization.27 On the student side, the antiradical attitude of society is a subjective reality and after social controversy has been carried out through the three stages as explained above, it can change into objective reality that has meaning for the madrasa people. The reality in society will always run dynamically in accordance with the dialectics of madrasas and society. So the anti-radicalism attitude of the madrasa students is not a static attitude that does not change, that attitude can change to be very radical if the dialectics between madrasas and society - in contrary - are able to contract the attitude of radicalism into an objective reality.

\section{Conclusion}

Social empowerment to strengthen the attitude of antiradicalism is more based on the utilization of social capital in the community to strengthen the attitude of tolerance and reduce the attitude of radicalism. Genduri, sambatan and kerja bakti are forms of humanitarian social activities which is a proportional place for tolerance and anti-radicalism socialization and internalization. Great motivation to always maintain harmony as the background of most people in the society who are still related greatly contribute to strengthening tolerance and reducing the simplistic dogmatic attitude of the community. Madrasa contract the reality of tolerance and antriradicalism of society into an objective reality that can be followed in the madrasa's daily life. Externalization of antriradicalism in madrasa can make this value the guideline that must be internalized in the lives of madrasa people. The success of madrasa adopting anti-radicalism is not

27 L. Peter and Thomas Luckmann Berger, The Social Construction of Reality A Treatise in the Sociology of Knowledge (New York: Doubleday, 1966). 
static but it is dynamic depending on the dialectics between the madrasas and the community.

\section{References}

Ahnaf, Mohammad Iqbal. "Struktur Politik Dan Deradikalisasi Pendidikan Agama Bagi Anak Muda Di Indonesia." Jurnal Pendidikan Islam 2, no. 1 (1970): 153. https://doi.org/10.14421/jpi.2013.21.153-171.

Amri Amzani. Antropologi \& Pembangunan Masyarakat Indonesia. Jakarta: Kencana, 2009.

Berger, L. Peter and Thomas Luckmann. The Social Construction of Reality A Treatise in the Sociology of Knowledge. New York: Doubleday, 1966.

Dixon, James M., and Peter L. Berger. "The Sacred Canopy: Elements of a Sociological Theory of Religion." Sociological Analysis 29, no. 1 (March 21, 2007): 40. https://doi.org/10.2307/3710433.

Garungan, W.A. Psikologi Sosial. Bandung: Eresco, 2008. Geertz, Clifford. Abangan Santri, Dan Priyayi Dalam Masyarakat Jawa, Terj. Aswab Mahasin. Jakarta: Pustaka Jaya, 1981.

Hatu, Rauf. "PERUBAHAN SOSIAL KULTURAL MASYARAKAT PEDESAAN (Suatu Tinjauan TeoritikEmpirik)." Journal Inovasi 8, no. 4 (2011): 1-11. https://scholar.google.co.id/scholar?hl=id\&as_sdt=0\%2C5 $\& q=$ PERUBAHAN+SOSIAL+KULTURAL+MASYARA KAT+PEDESAAN\&btnG $=$.

Lukens-Bull, Ronald. "The Traditions of Pluralism, Accommodation, and Anti-Radicalism in the Pesantren Community." Journal of Indonesian Islam 2, no. 1 (2008): 1-15. https://doi.org/10.15642/JIIS.2008.2.1.1-15.

Masduqi, Irwan. "Deradikalisasi Pendidikan Islam Berbasis 
Khazanah Pesantren." Jurnal Pendidikan Islam 2, no. 1 (1970): 1. https://doi.org/10.14421/jpi.2013.21.1-20.

Maulana, Dirga. "The Exclusivism of Religion Teachers: Intolerance and Radicalism in Indonesian Public Schools." Studia Islamika 24, no. 2 (2017): 395-401. https://doi.org/10.15408/sdi.v24i2.5707.

Nawari Ismail. "Konflik Umat Beragama Dan Budaya Lokal." Jakarta: Dirjend Dikti, 2010.

Putnam, R, R. Putnam, RD Putnam, D Putnam, and Robert PUTNAM. "The Prosperous Community: Social Capital and Public Life." The American Prospect, 1993.

Rubaidi. Radikalisme Islam, Nahdlatul Ulama; Masa Depan Moderatisme Islam Di Indonesia. Yogyakarta: Logung Pustaka, 2010.

Susanto, Nanang Hasan. "Menangkal Radikalisme Atas Nama Agama Melalui Pendidikan Islam Substantif." Nadwa 12, no. 112018$)$ : 65. https://doi.org/10.21580/nw.2018.12.1.2151.

Tilaar, H.A.R. Perubahan Sosial Dan Pendidikan, Pengantar Pedagogik Transformatif Untuk Indonesia. Jakarta: PT. Grasindo, 2002.

Zainiyati, Husniyatus Salamah. "Curriculum, Islamic Understanding and Radical Islamic Movements in Indonesia." Journal of Indonesian Islam 10, no. 2 (2016): 285-307. https://doi.org/10.15642/JIIS.2016.10.2.285-308. 